\title{
A Summary and Analysis of Warrantless Arrest Statutes for Domestic Violence in the United States
}

Journal of Interpersonal Violence $26(14) 2811-2833$

(C) The Author(s) 2011

Reprints and permission: http://www. sagepub.com/journalsPermissions.nav

DOI: I0.II 77/08862605I0390945 http://jiv.sagepub.com

(SAGE

\section{April M. Zeoli,' Alexis Norris,' and Hannah Brenner'}

\begin{abstract}
In the United States, all 50 states and the District of Columbia have enacted statutes that allow police officers to make warrantless arrests for domestic violence given probable cause; however, state laws differ from one another in multiple, important ways. Research on domestic violence warrantless arrest laws rarely describe them as anything more than discretionary, preferred, or mandatory, either within their analyses or within the texts of their publications; researchers, and their audiences, may not be aware of the vast and potentially important differences among these laws. In this article, we list the domestic violence warrantless arrest laws for each state, and discuss them in terms of five common elements: the phrasing of the arrest authority; whether additional factors to domestic violence are required to trigger the arrest authority; qualifications to the arrest authority; time limits for warrantless arrest to occur; and whether police officers are required to report why they made a dual or no arrest. We then analyze the common elements of the laws, paying particular attention to how they may encourage or discourage the arrest of alleged domestic violence perpetrators. It is critical that researchers, advocates, and policymakers are aware of these variations
\end{abstract}

\footnotetext{
'Michigan State University, East Lansing
}

\section{Corresponding Author:}

April M. Zeoli, Michigan State University, 540 Baker Hall, East Lansing, MI 48824

Email: zeoli@msu.edu 
in state statutes when conducting or interpreting research or making policy recommendations.

\section{Keywords}

domestic violence, legal intervention, batterers, criminology

In the United States in 2005 , more than $60 \%$ of the more than 564,000 nonfatal, violent incidents perpetrated by intimate partners were reported to the police (Catalano, 2007). Whether police arrested the alleged perpetrators of domestic violence (DV) in response to these reports varied widely, based in part on state law governing the ability or duty of an officer to make a warrantless arrest. Although all 50 states and the District of Columbia currently allow officers to make warrantless arrests for DV, state laws differ from one another in multiple, important ways. This article details, compares, and analyzes differences between state DV warrantless arrest laws but begins with a brief history.

Historically, DV crimes were considered family matters that were best handled in the privacy of the home. Prior to the late 1970s, it was not uncommon for law enforcement to ignore calls from DV victims. Police officers who responded to DV calls generally attempted to diffuse the immediate situation by employing conflict resolution tactics, including mediation and separation (Buzawa \& Buzawa, 1993; Maxwell, Garner, \& Fagan, 2001). Under the common law, officers were precluded from making warrantless arrests for misdemeanor crimes of DV, as most DV crimes are classified (Buzawa \& Buzawa, 2003), even if there was probable cause to suggest that the alleged perpetrator committed the crime (Harvey, 1994). Warrantless arrests could be made only in circumstances where the officer witnessed an act of DV (Miller, 2005).

With the advent of the 1980s came many factors that coalesced to provide circumstances ripe for passage of laws authorizing police officers to make warrantless arrests when acts of DV were committed outside of their presence (Buzawa \& Buzawa, 1993; Schmidt \& Sherman, 1993). The women's movement continued to gain in strength and agitated for DV to be treated as a crime (Buzawa \& Buzawa, 1993). Concurrently, the political landscape was less rehabilitative and more punitive toward criminal offenders (Buzawa \& Buzawa, 1993); for example, the juvenile justice system experienced changes that made it easier for juveniles to be charged and tried as adults and imposed increased retributive sanctions on such offenders to "provide consequences to the lawbreaker" (Bazemore \& Umbreit, 1995). Furthermore, the U.S. Attorney 
General's Family Violence Task Force recommended arrest as an appropriate response to family violence (Hart, 1984). Arguably, the most prominent catalyst for the passage of DV warrantless arrest laws was the Minneapolis Domestic Violence Experiment (MDVE), a study that evaluated the effects of various law enforcement responses on the recurrence of DV incidents. The results of the MDVE suggested that arresting a DV perpetrator decreased the likelihood of future violence against the same victim when compared with other strategies (Sherman \& Berk, 1984). In an effort to create a more punitive, effective, and consistent police response, many states implemented statutes that limited officer discretion in whether to make DV arrests.

The proliferation of state laws allowing warrantless arrests for misdemeanor DV on a showing of probable cause that the alleged perpetrator committed a crime raises serious constitutional issues. The concept of probable cause is largely a judicial construct and difficult to define precisely. As noted by Miller and Wright (2007), "Probable cause is constantly applied but only rarely defined." The most widely accepted definitions of probable cause come from the U.S. Supreme Court decisions Brinegar v. United States (1949) and Beck v. Ohio (1964). In Brinegar, the Court emphasized a focus on probabilities in defining probable cause:

It has come to mean more than bare suspicion: Probable cause exists where the facts and circumstances within [the officers'] knowledge and of which they had reasonably trustworthy information [are] sufficient in themselves to warrant a man of reasonable caution in the belief that an offense has been or is being committed. (Brinegar v. United States, 1949)

Furthermore, in Beck v. Ohio (1964), the Supreme Court found that in the determination of whether probable cause existed, the facts and circumstances must suggest that the officer had reasonably trustworthy information that the alleged perpetrator committed an offense. This information can come from varied sources such as victims, witnesses, informants, and police officers themselves (Miller \& Wright, 2007).

The U.S. Supreme Court has never directly considered the constitutionality of warrantless arrests for misdemeanor DV crimes. In the dissenting opinion in Welsh v. Wisconsin (1984), Justices White and Rehnquist stated, "we have never held that a warrant is constitutionally required to arrest for nonfelony offenses occurring out of the officer's presence." Some scholars suggest that there exists a presumption of constitutionality evidenced by the enactment of warrantless arrest statutes in every state and by the provision of 
the federal Violence Against Women Act of 1994 that required states and local governments to adopt mandatory or proarrest policies to receive funding under the Act (Cunningham, 1997).

DV warrantless arrest laws have been the subject of research and are often classified in the research by the amount of discretion an officer has to make on an arrest. Statutes that allow the officer to decide whether to arrest (often using the phrase "may arrest") are termed discretionary; those that allow the officer to decide whether to arrest, but also convey a state preference for arrest, are termed preferred; and statutes that seem to require officers to arrest (often stating that officers "shall arrest") are termed mandatory. Researchers have examined the effects of mandatory and preferred arrest laws on outcomes such as dual arrest, where both parties to the event are arrested (Hirschel, Buzawa, Pattavina, Faggiani, \& Reuland, 2007), and intimate partner homicide (Iyengar, 2009). However, researchers often do not agree on the classification of individual arrest laws as discretionary, preferred, or mandatory, leading to difficulties in making meaningful conclusions about the impacts of the laws.

Discrepancies in the ways the laws are classified often cannot be explained by changes in state laws over time. Possible sources of variation among researchers include interpretive differences, differences in classification criteria, confusion, and error. Interpretive differences may occur because of the complexity of the laws: researchers may interpret the text of the laws differently. Furthermore, researchers may create differing criteria for their classification schemes. For example, some laws contain both "may" and "shall arrest" provisions, which could lead one researcher to classify the law as discretionary and another as mandatory. Other sources of difference include error or confusion: a research assistant may have erred in the compilation of statutes or interpreted the laws incorrectly. There is more than one example in the literature in which an arrest law is incorrectly identified as pertaining to warrantless arrest for commission of misdemeanor DV when it actually referred to arrest for violation of a DV protection order.

Our aim in this article is to enumerate and clarify key elements of state statutes that direct police officers on their power or duty to make a warrantless arrest when called to the scene of DV. Research on DV warrantless arrest laws rarely describe them as anything more than discretionary, preferred, or mandatory, either within their analyses or within the texts of their publications; researchers, and their audiences, may not be aware of the vast and potentially important differences among the laws. Advocates, policy makers, and researchers can use the information presented here to better understand existing research on these laws. Researchers can also develop more nuanced questions and hypotheses regarding DV warrantless arrest laws and their 
effects and use the data presented here in investigations of these laws, including policy implementation analyses, possibly hastening the proliferation of research in this area.

In this article, we list the DV warrantless arrest laws for each state, breaking them down into their common elements. We do not seek to classify these laws as mandatory, preferred, or discretionary. Instead, we seek to present the language of each law with as little interpretation as is required to provide those interested in these laws the information needed to make their own interpretations and classifications. In the Discussion section, we analyze elements of the laws, paying particular attention to how they may encourage or discourage the arrest of alleged DV perpetrators.

\section{Method}

A master list was created of existing DV warrantless arrest law citation compilations (American Bar Association Commission on Domestic Violence, 2007; Hirschel et al., 2007; Iyengar, 2006; Miller, 2004). The text of each statute, as it read in April 2010, was found on Lexis Nexis and examined to determine whether the law met our case definition described below. For some states, multiple statutes that fit the case definition were identified; both statutes were included in the analysis unless one statute simply referred back to the other regarding arrest, in which case only the referenced statute was included.

$D V$ warrantless arrest laws were defined as those laws that authorize a police officer to arrest an alleged perpetrator of DV without a warrant when on a DV call. The mention of the crime of DV was determined by (a) use of a phrase commonly understood to mean DV, such as family violence, (b) reference to the relationship of the victim to the perpetrator as being intimate, such as a household member or spouse, or (c) whether the statute referenced other statutes criminalizing DV. If a statute did not specifically mention DV, whether the statute broadly covered misdemeanors, as DV incidents are often characterized, was determined. It is important to note that we did not analyze the special circumstances of arrest for protection order violations or complaints of DV victimization by both parties, nor did we analyze case law, opinions, or notes attached to the statutes.

Two researchers carefully read each statute to identify elements common among them and analyzed the laws based on these common elements. A table was developed (Table 1), and the laws were reread multiple times by each researcher to both fill in and verify the accuracy of the information. We also examined the legislative history of each statute to determine when the 


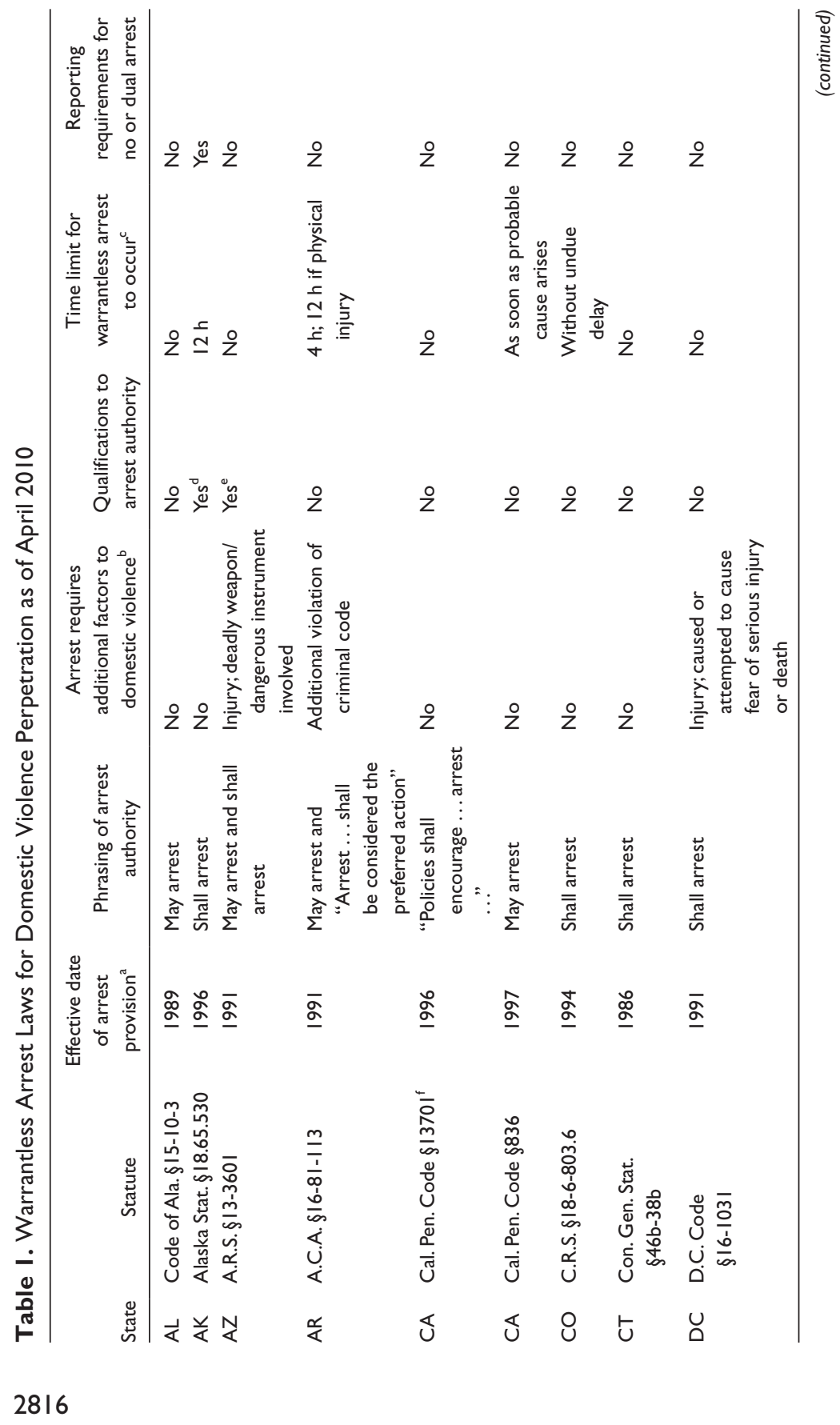

Downloaded from jiv.sagepub.com at MICHIGAN STATE UNIV LIBRARIES on October 9, 2014 


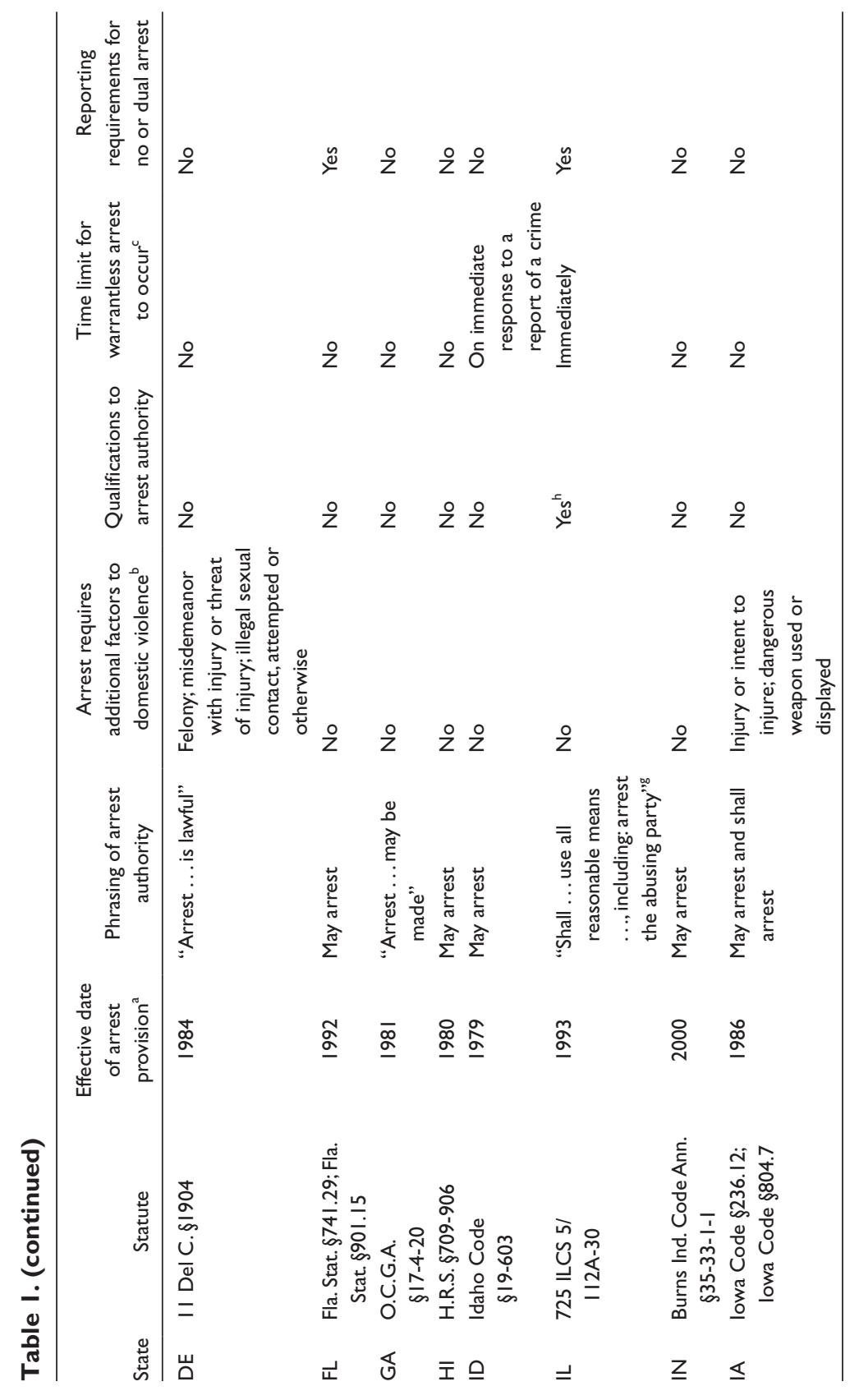




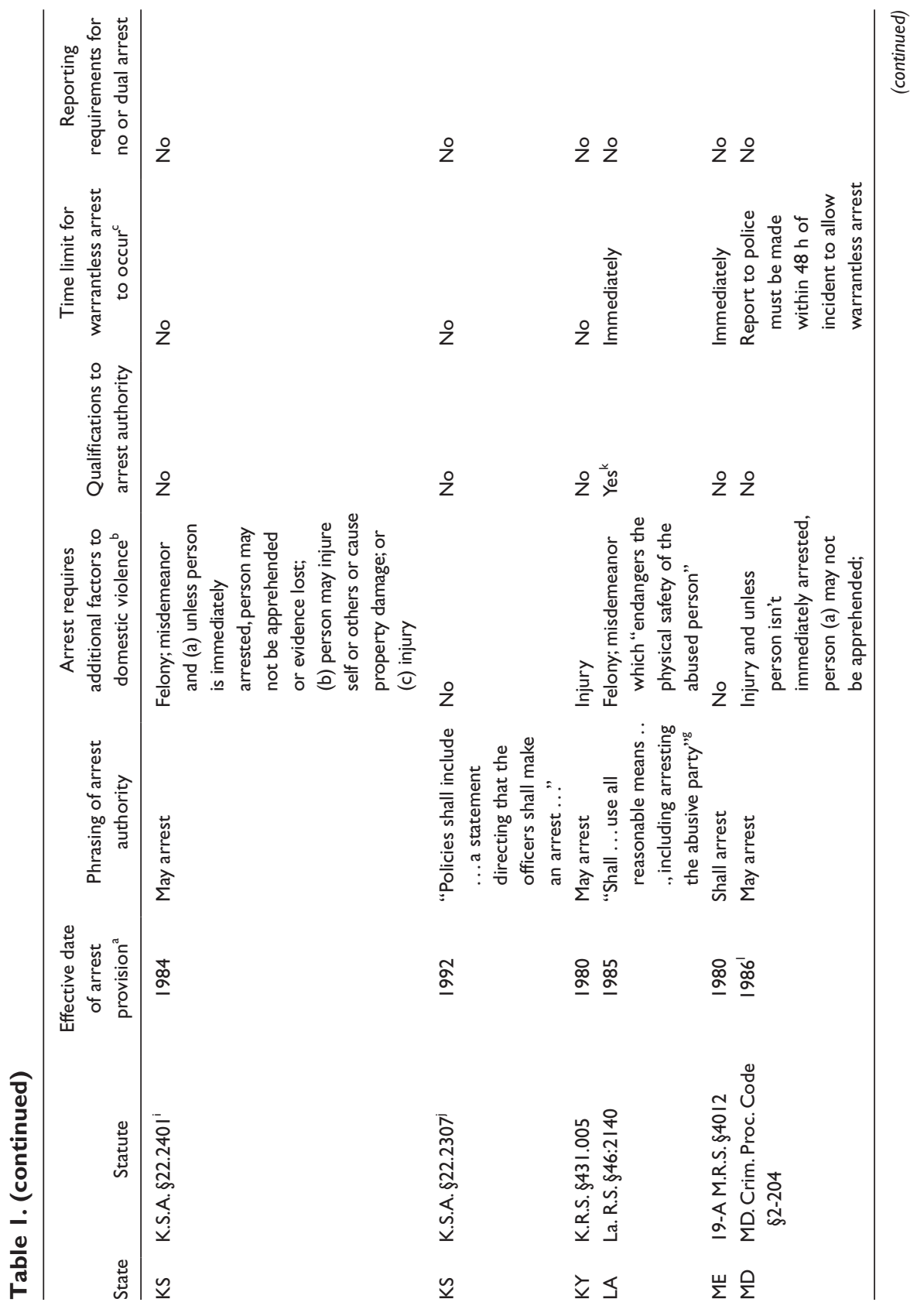




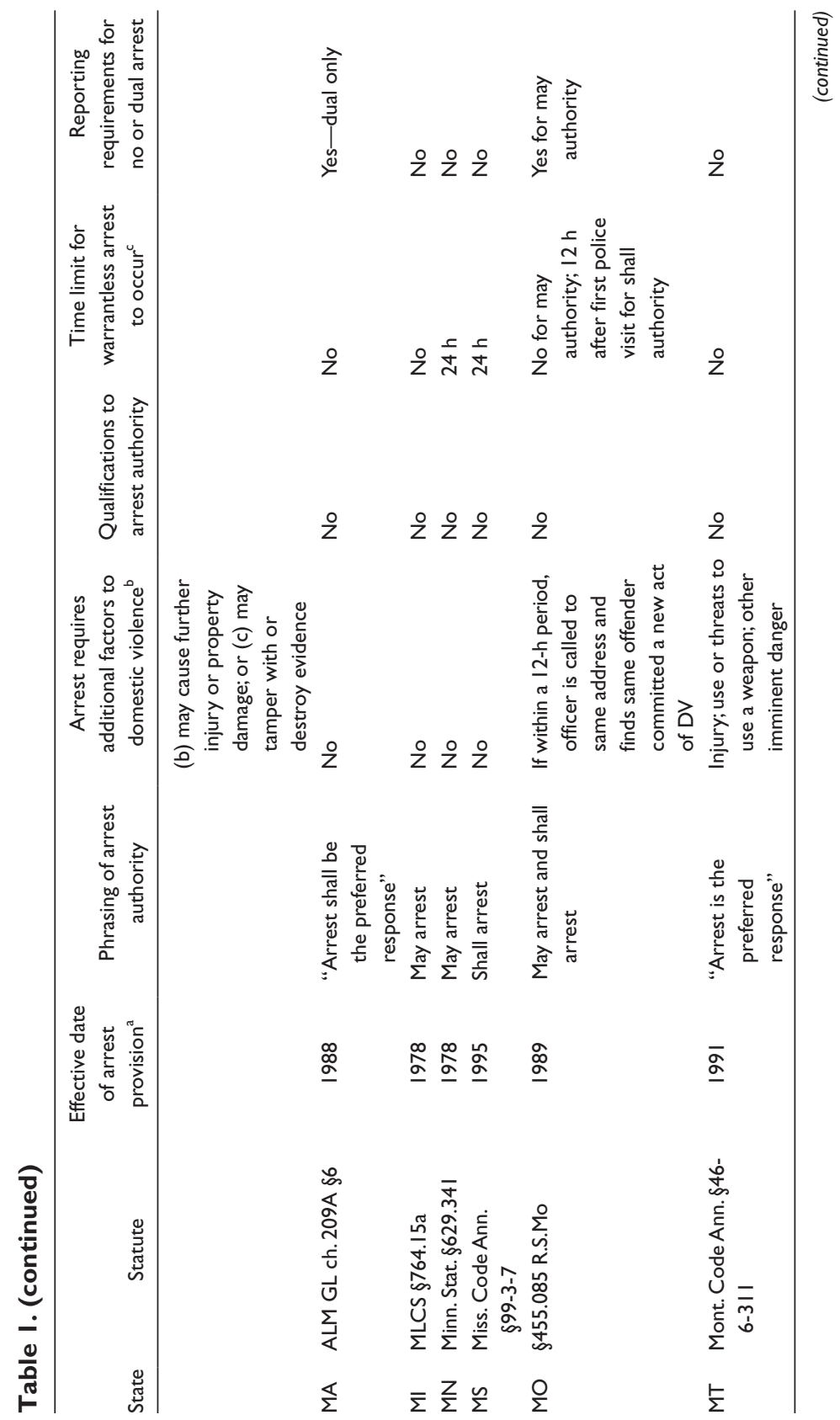




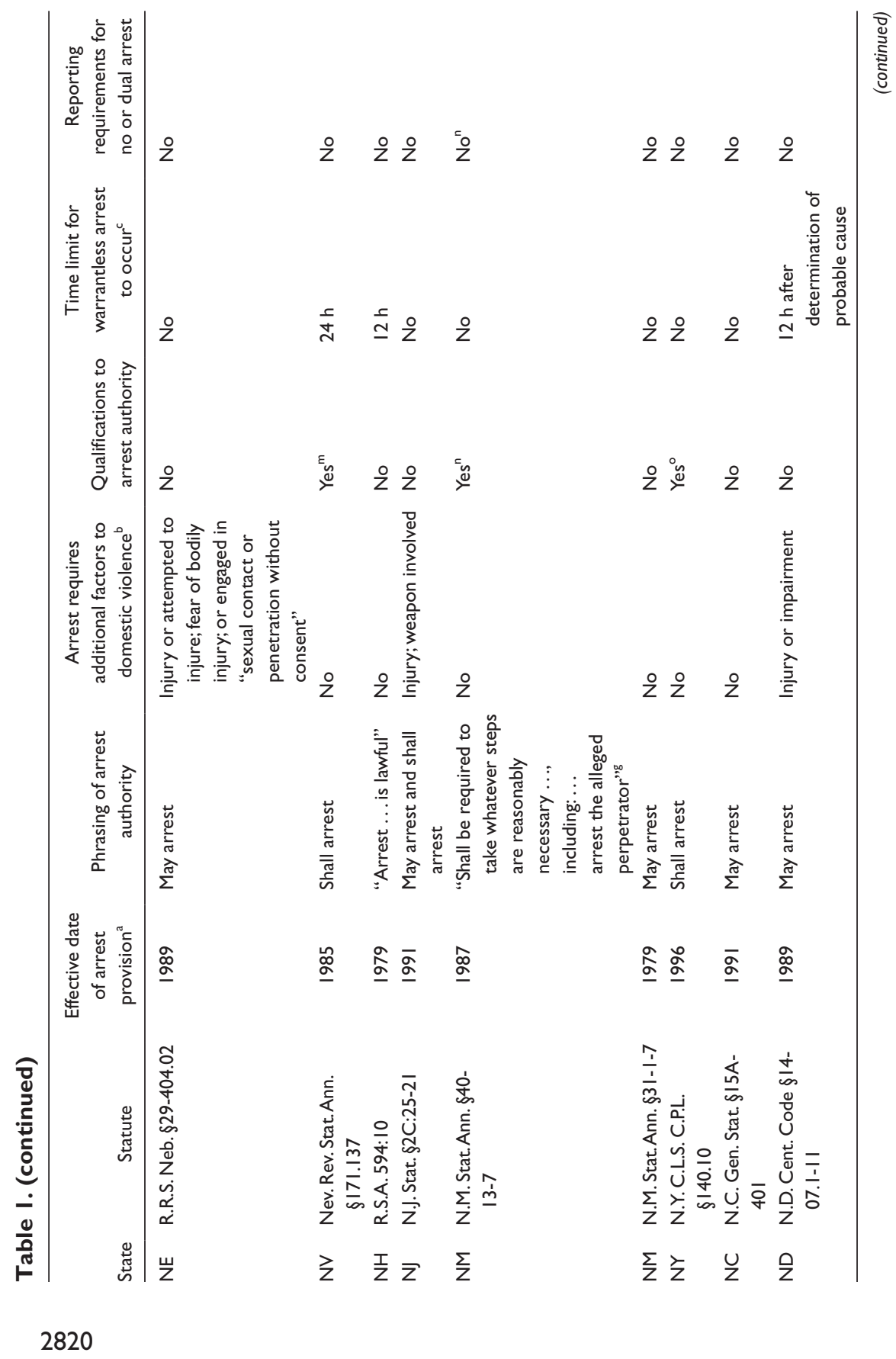

Downloaded from jiv.sagepub.com at MICHIGAN STATE UNIV LIBRARIES on October 9, 2014 


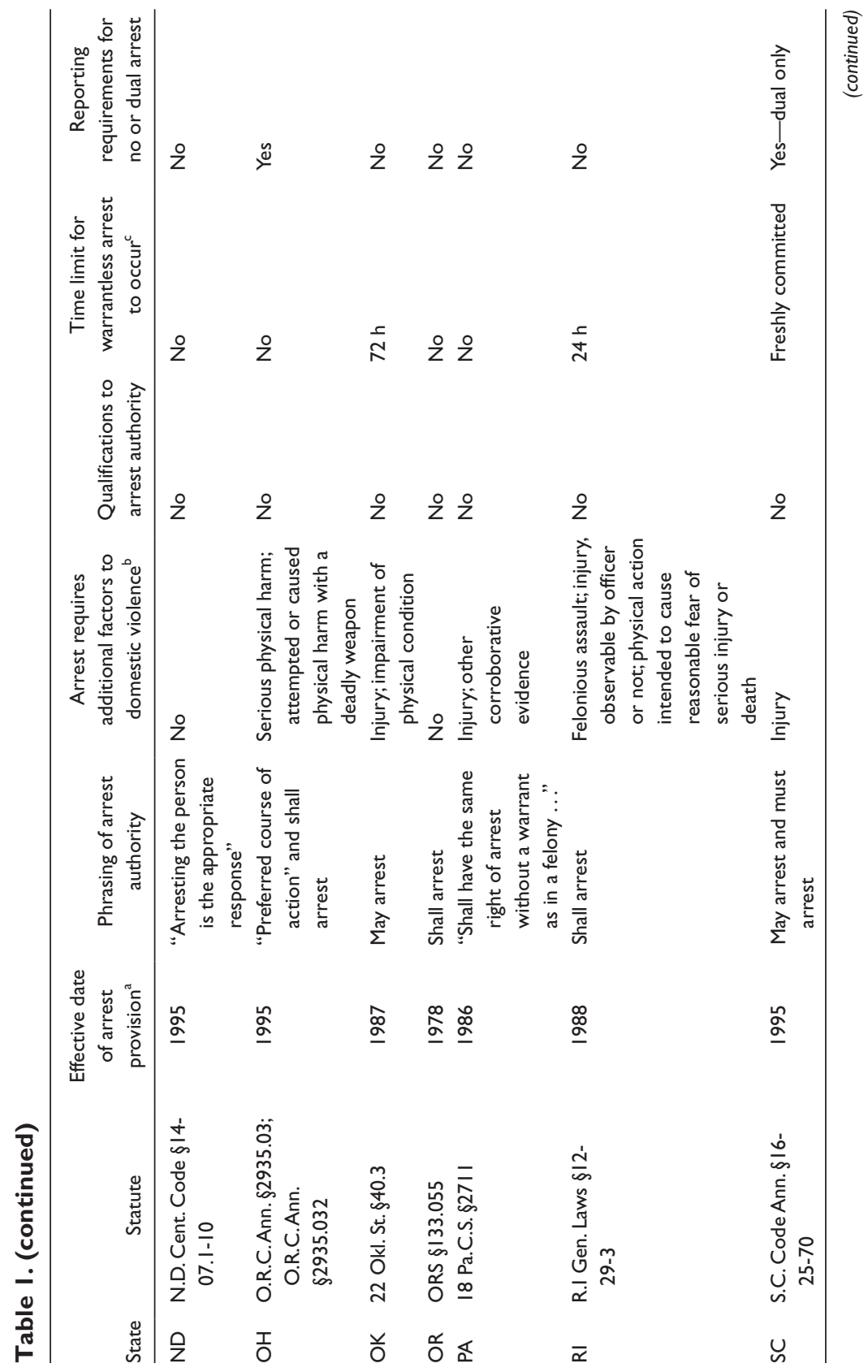




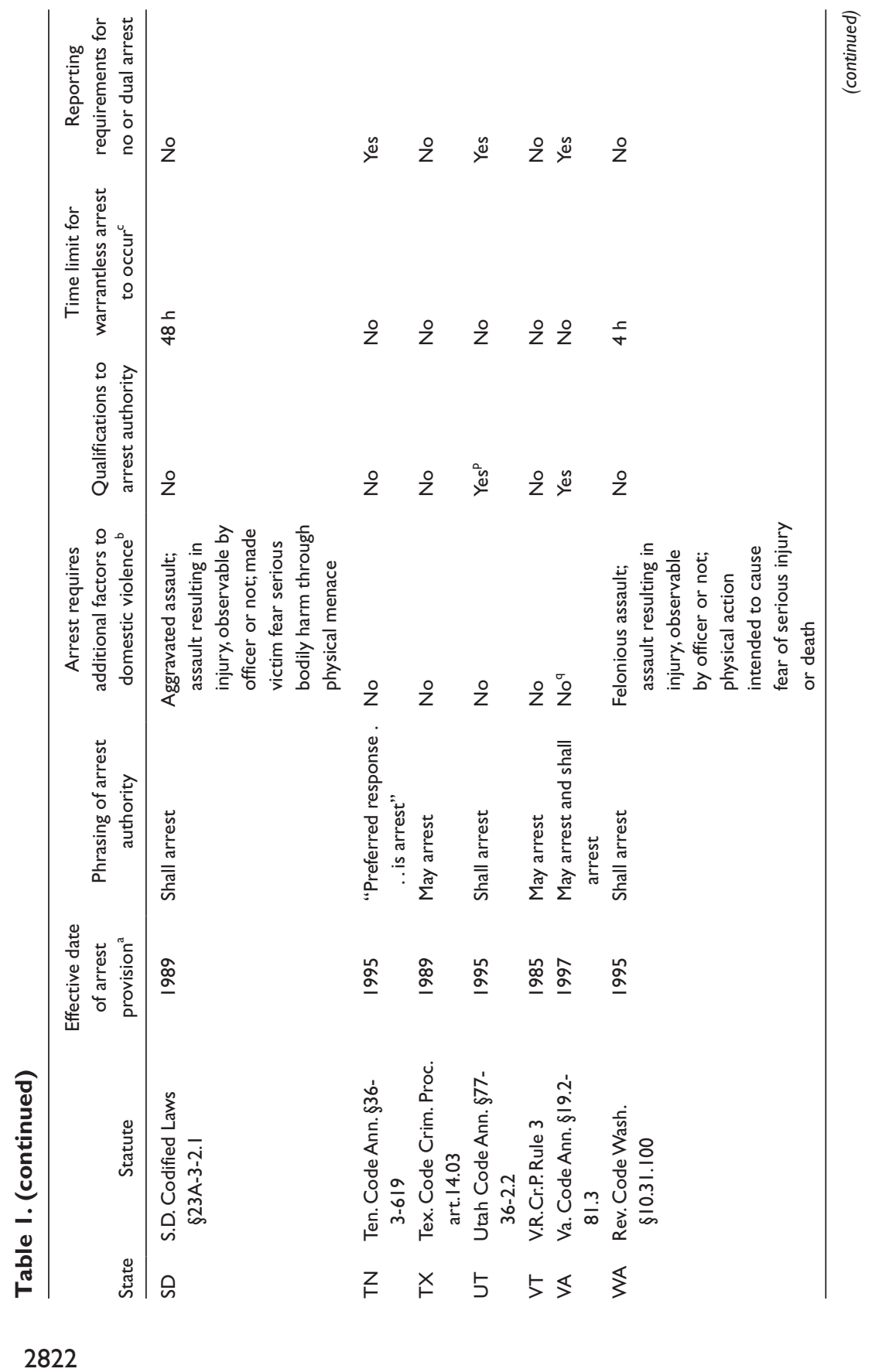

Downloaded from jiv.sagepub.com at MICHIGAN STATE UNIV LIBRARIES on October 9, 2014 


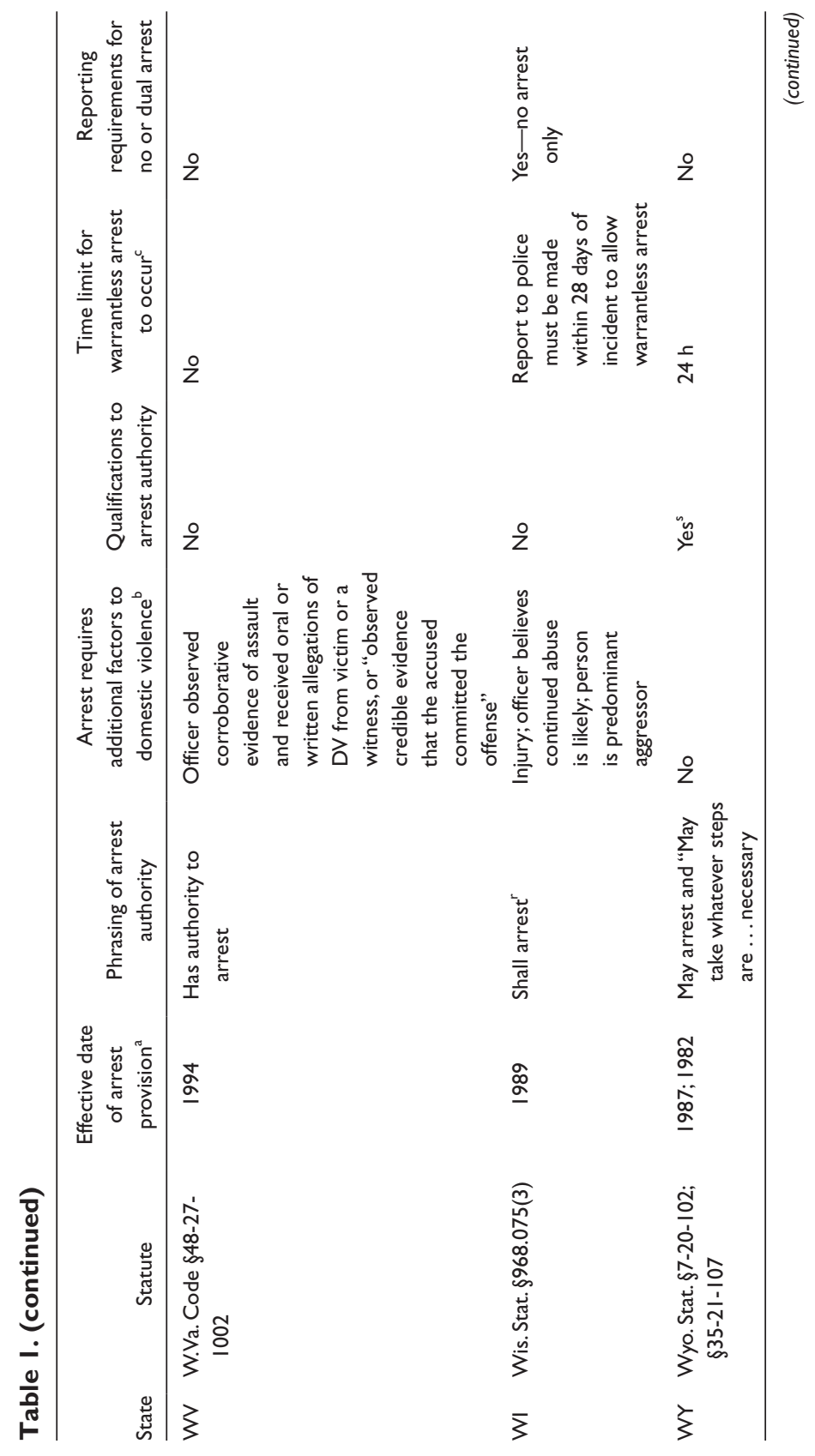




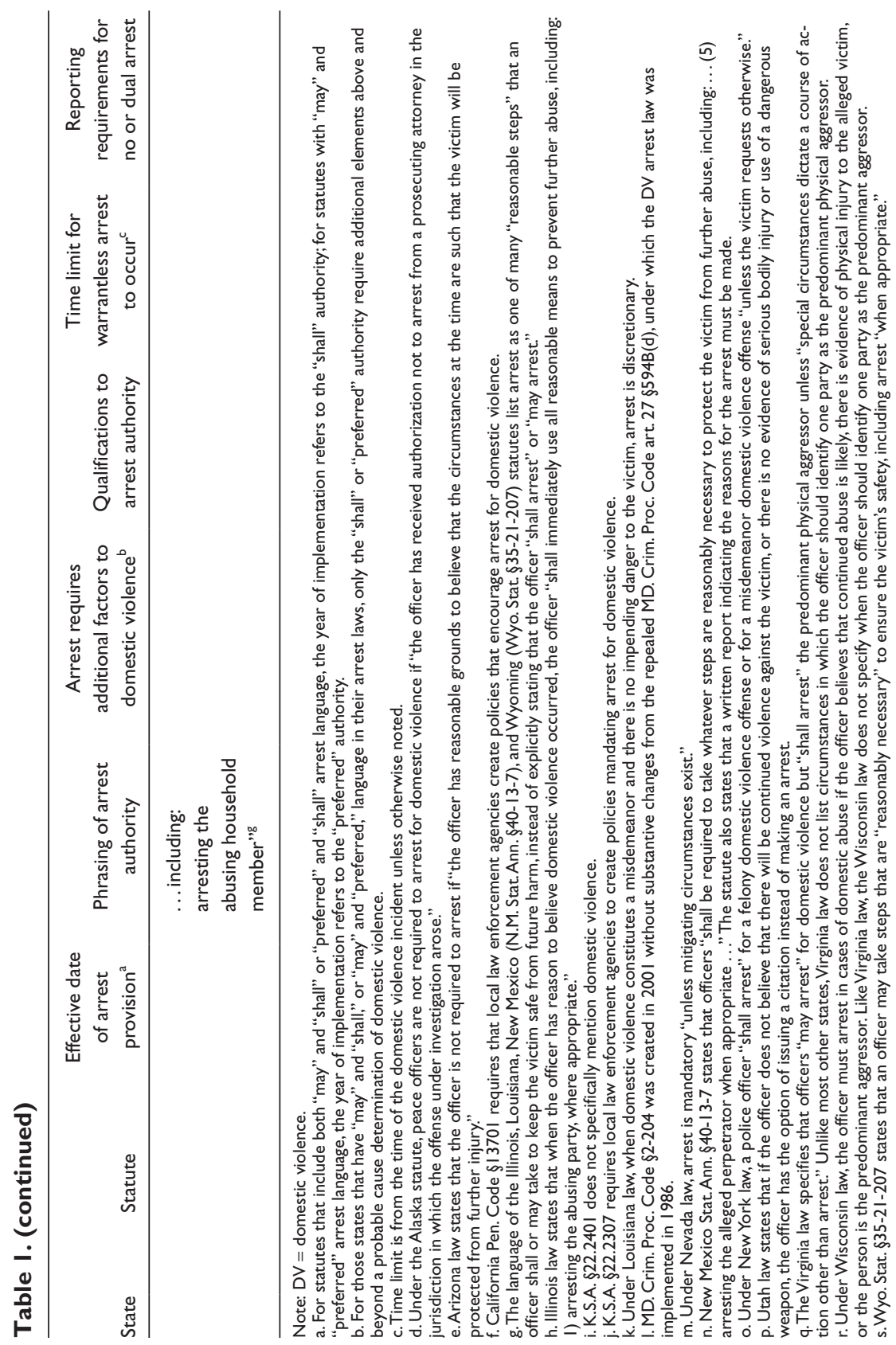


language pertaining to a police officer's authority to arrest for DV was made into law. Therefore, the implementation dates presented in Table 1 refer only to the language that specifically gives police the authority to arrest and are not necessarily the implementation dates for other elements of the statutes. For statutes with multiple arrest provisions (for example, an officer "may arrest," but "shall arrest" if the victim sustained an injury), the implementation dates refer to the stronger of the two provisions. Also, a state might have had a "may arrest" provision prior to codifying a "shall arrest" provision, however such law changes are not represented in this study.

\section{Results}

Each of the 50 states and the District of Columbia have legislation allowing officers to make a warrantless arrest at the scene of DV. The statutes take two approaches: DV is either included in a list of offenses for which the police have the authority to make a warrantless arrest or warrantless arrest is included as one of the actions police could or should take when responding to DV. Five common elements were identified in the laws, and these elements, along with law citations and implementation dates, are found in Table 1.

The fourth column of Table 1 represents the first of the five common elements: the phrase used to describe a police officer's authority to arrest. The majority of statutes use the phrases "may arrest" or "shall arrest" to describe this authority. Based on the statutes included in this study, 21 states specify only that police officers "may arrest," have the "authority to arrest," or may lawfully arrest, without a warrant, an alleged perpetrator of DV. Four states have statutes that assert only that arrest is "appropriate" or "preferred." Fourteen states and the District of Columbia have statutes that state only that officers "shall" or "must arrest" for DV.

In addition, eight state statutes with "may arrest" provisions also have "shall arrest" or "preferred arrest" provisions that apply when specified factors additional to DV are present, as discussed below. For example, Arizona law states that officers may arrest for DV however, if the DV involves an injury to the victim or use of a deadly or dangerous weapon, officers shall arrest. The Louisiana law is presented a bit differently, stating that officers "shall arrest" unless "there is no cause to believe there is impending danger," in which case arrest is at the officer's "discretion" (La. R.S. §46:2140).

The statutes of Illinois, Louisiana, and New Mexico (N.M. Stat. Ann. $\S 40-13-7)$ list arrest as one of numerous "reasonable steps" an officer shall take to keep victims of DV safe from future harm. Implemented 8 years before N.M. Stat. Ann. §40-13-7, New Mexico has an additional statute included 
Table 2. Summary of States With Common Elements Contained in DV Warrantless Arrest Statutes by Phrasing of Arrest Authority

\begin{tabular}{|c|c|c|c|c|c|}
\hline $\begin{array}{l}\text { Phrasing } \\
\text { of arrest } \\
\text { authority }\end{array}$ & $\begin{array}{l}\text { No additional } \\
\text { elements }\end{array}$ & $\begin{array}{c}\text { Arrest } \\
\text { requires } \\
\text { additional } \\
\text { factors }\end{array}$ & $\begin{array}{l}\text { Qualifications } \\
\text { to arrest } \\
\text { authority }\end{array}$ & $\begin{array}{c}\text { Time } \\
\text { limits for } \\
\text { warrantless } \\
\text { arrest to } \\
\text { occur }\end{array}$ & $\begin{array}{l}\text { Reporting } \\
\text { requirements } \\
\text { for no or } \\
\text { dual arrest }\end{array}$ \\
\hline May & $\begin{array}{l}\mathrm{AL}, \mathrm{GA}, \mathrm{HI} \\
\mathrm{IN}, \mathrm{MI}, \mathrm{NM}^{\mathrm{a}} \\
\mathrm{NC}, \mathrm{TX}, \mathrm{VT}\end{array}$ & $\begin{array}{l}\text { DE, KS } S^{b}, K Y \\
\text { MD, NE, } \\
\text { ND }, \text { OK, } \\
\text { PA,WV }\end{array}$ & WY & $\begin{array}{l}\mathrm{CA}^{\mathrm{d}}, \mathrm{ID}, \\
\mathrm{MD}, \mathrm{MN}, \\
\mathrm{NH}, \mathrm{ND}^{\mathrm{c}}, \\
\mathrm{OK}, \mathrm{WY}\end{array}$ & $\mathrm{FL}$ \\
\hline $\begin{array}{l}\text { May and } \\
\text { preferred }\end{array}$ & & $A R$ & & AR & \\
\hline Preferred & $C A^{e}, N D^{f}$ & MT & & & $\mathrm{MA}, \mathrm{TN}$ \\
\hline $\begin{array}{l}\text { May and } \\
\text { shall }\end{array}$ & & $\begin{array}{l}\text { AZ, IA, LA, } \\
\text { MO, NJ, } \\
\text { SC }\end{array}$ & $A Z$, LA,VA & LA, MO, SC & MO, SC,VA \\
\hline $\begin{array}{l}\text { Preferred } \\
\text { and shall }\end{array}$ & & $\mathrm{OH}$ & & & $\mathrm{OH}$ \\
\hline Shall & $\mathrm{CT}, \mathrm{KS}^{\mathrm{g}}, \mathrm{OR}$ & $\begin{array}{c}\text { DC, RI, SD, } \\
\text { WA,WI }\end{array}$ & $\begin{array}{l}\text { AK, IL, NV, } \\
\text { NM }^{\text {h }}, N Y, \\
\text { UT }\end{array}$ & $\begin{array}{l}\text { AK, CO, IL, } \\
\text { ME, MS, } \\
\text { NV, RI, } \\
\text { SD,WA, } \\
\text { WI }\end{array}$ & $\begin{array}{l}\text { AK, IL, UT, } \\
\text { WI }\end{array}$ \\
\hline
\end{tabular}

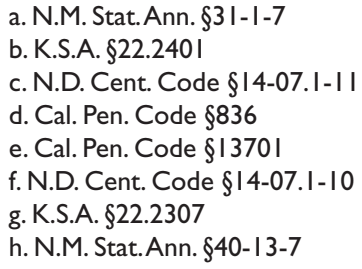

in the analysis that pertains to arrests for DV that states that an officer "may arrest" for DV (N.M. Stat. Ann. §31-1-7).

Kansas and California are likewise notable for each having two entries in Table 1. K.S.A. \$22.2401 does not specifically mention DV; however misdemeanor DV is implicitly included under the broad category of misdemeanor crimes for which an officer may arrest. K.S.A. \$22.2307 instructs police departments to create their own policies requiring that officers "shall arrest" for DV. Both laws are included in this analysis because in the first, the state broadly grants arrest authority to police, and the second strengthens the arrest 
language pertaining to DV through local police policy. Similarly, California Penal Code $\$ 836$ grants police officers the authority to arrest for DV, and California Pen. Code $\$ 13701$ mandates that police departments create policies in which arrest for DV is "encouraged."

Table 2 lists the states that have statutes containing the remaining four common elements, broken down by their phrasing of the police officer's arrest authority.

Most states only require that an officer have probable cause to believe that DV occurred to have the authority to arrest, but twenty-three states require more than probable cause, as listed in the fifth column of Table 1. The most commonly required additional factor is a visible injury to the alleged victim, although some states have alternate requirements. For example, Maryland law requires both the presence of an injury and one of another three factors justifying immediate arrest, such as property damage or the risk of further injury; Iowa requires injury, intent to injure, or the use or display of a deadly weapon.

For states with multiple arrest provisions (e.g., both "may" and "shall arrest" provisions) and an additional requirement to probable cause, the additional factor triggers the stronger of the arrest provisions. For example, in Arkansas, a police officer "may arrest" for DV, but arrest is the preferred action if the alleged perpetrator committed an additional violation of the criminal code. Multiple states that only have "may arrest" language also require additional factors to trigger the arrest authority. By requiring the presence of factors additional to probable cause, these provisions may serve to place limits on when an officer "shall" or "may arrest."

Column 6 of Table 1 lists whether each statute contains language qualifying an officer's authority to arrest. These qualifications tend to be vague in wording and either provide circumstances under which arrest is not required or otherwise allow for police discretion as to whether to arrest. The use of qualifying language is most common in statutes with "shall arrest" provisions. For example, in New York, a police officer does not have to arrest for misdemeanor DV if the victim requests that an arrest not be made, and both Arizona and Louisiana laws allow the police officer to avoid arrest if the officer believes the victim of misdemeanor DV is not in danger of further injury. However, some states have more vague provisions that state that a police officer shall arrest "when appropriate" (N.M. Stat. Ann. $\S 40-13-7)$ or unless "special circumstances dictate a course of action other than arrest" (Va. Code Ann. §19.2-81.3).

Twenty-two states include a time limit by which police must make an arrest to do so without a warrant. Time limits for arrest, represented in 
column 7 of Table 1, are often a specified number of hours after the DV incident, with the window of opportunity closing anywhere from $4 \mathrm{~h}$ after the incident (AR and WA) to allowing warrantless arrest if a police report was made within 28 days of the incident (WI). In some statutes, the time limit is seemingly more subjective; for example, California law states that police officers may arrest if they do so "as soon as probable cause arises," and South Carolina states that police may arrest if the person to be arrested "freshly committed" DV.

The final analyzed common element of the DV warrantless arrest statutes, listed in column 8 of Table 1, is whether there are additional reporting requirements for DV cases in which the officer either does not make an arrest or arrests both parties. States frequently require officers to make a DV report if they go on a DV call; however 11 states have a specific reporting requirement for officers who make no arrest or a dual arrest. Massachusetts and South Carolina require a report only in cases of dual arrest, and Wisconsin requires a report only in cases of no arrest.

\section{Discussion}

There is great diversity among the state statutes enabling the warrantless arrest of alleged perpetrators of DV. The statutes' common elements, identified here, may encourage or discourage arrest, or increase the amount of discretion a police officer has in making the decision to arrest. Due to these potential effects on arrest, and further implications on DV recidivism, it is critical that researchers, advocates, and policymakers are aware of these variations when conducting or interpreting research or making policy recommendations.

As statutes providing more than one arrest authority (e.g., statutes with both "may" and "shall arrest" provisions) most frequently require the presence of factors additional to probable cause for DV to trigger the stronger of the arrest provisions, the enumeration of additional factors may decrease discretion for DV cases that the state considers to be in greater need of intervention. Additional factors provisions do not appear to simply define when probable cause to arrest is present in a DV case. For example, the New Jersey statute states that an officer may arrest if "there is probable cause to believe that an act of domestic violence has been committed ..." but shall arrest if there is "probable cause to believe domestic violence has occurred" and the victim has signs of injury or there is also probable cause to believe a weapon was involved in the incident (N.J. Stat. §2C:25-21). In other words, probable cause must be present to trigger arrest authority in general, but probable cause plus an additional factor triggers a removal of some amount 
of the police officer's discretion in the decision to arrest. In this way, it appears that additional factors are included in some arrest laws to ensure that DV cases that are more severe are more likely to result in arrest.

The use of qualifying language is mainly found in laws with "shall arrest" provisions. These phrases describe situations in which arrest is not compulsory and often require judgment from a police officer as to when those situations apply. For example, Nevada's statute, which states that a police officer shall arrest "unless mitigating circumstances exist," requires a determination of what circumstances may mitigate arrest and whether those circumstances are present. Such qualifications in the law may lead to confusion among police departments and officers as to when arrest is or is not required. Local jurisdictions and police officers may have their own interpretations of what constitutes a mitigating circumstance or may choose to disregard qualifying language and simply institute a policy requiring arrest if the law grants them discretion to do so. These qualifications may also make it difficult for victims of DV to predict whether calling the police will result in an arrest, which could influence their decisions to call.

Limits on the time police have to make warrantless arrests of suspected DV offenders may also play a role in whether an arrest occurs. Roughly, half of all DV offenders leave the scene before police arrive (Feder, 1996), complicating the possibility of warrantless arrest within a short time span. Once outside of the prescribed time limit, police may not be motivated to pursue an arrest warrant, particularly if it requires additional cooperation from the victim. It is possible that in states with time limits on warrantless arrest, perpetrators are able to avoid arrest altogether by leaving the scene after a call to the police has been made. In 2009, in the belief that restrictive time limits on warrantless arrest may be a factor in revictimization, the Minnesota legislature expanded their statute's time limit from 12 to 24 hours in an effort to prevent the perpetrator from "re-assaulting the victim" (Cook, 2009). Whether time limits on warrantless arrest increase the risk of future assaults on victims is a worthy research question.

Eleven states have reporting requirements for officers who either fail to arrest or arrest both parties on a DV call; most of these requirements are included in "preferred" or "shall arrest" laws. These reporting requirements can be interpreted as encouraging arrest by placing a burden on those officers who do not arrest and discouraging dual arrests by placing a burden on those officers who arrest both parties. Research suggests that states with what were termed "mandatory" arrest laws had increased rates of dual arrests (Hirschel et al., 2007). In the future, researchers may examine whether the dual arrest rate is reduced in states with dual arrest reporting requirements. Interestingly, 
instead of requiring a report of why no arrest was made at the scene of DV, New Mexico Stat. Ann. §40-13-7 requires a written report indicating reasons why an arrest occurred. This places an additional burden on officers who arrest, possibly discouraging arrest.

The classification of these statutes as discretionary, preferred, or mandatory arrest laws relies heavily on interpretation. In general, the word "shall" indicates a mandatory action, however the qualifications added to many of these laws allow more discretion to the police officer than the word "shall" implies. Some of the statutes that use the phrase "shall arrest" do not seem to mandate arrest when the qualifications included in the provision are taken into account. Further complicating law categorization are statutes that have a combination of "may," "preferred," and "shall arrest" provisions that are contingent on specific circumstances surrounding the DV incident (e.g., whether a deadly weapon was involved). For example, Missouri has one such "may" and "shall" law, and a review of the literature finds this law classified as recommended (Iyengar, 2006), mandatory (Hirschel et al., 2007), and discretionary (American Bar Association Commission on Domestic Violence, 2007).

The number and diversity of elements included in DV arrest laws lead to circumstances where laws that are actually quite different are treated as the same in the research. To the authors' knowledge, there is no research that examines whether the differences among these laws discussed here impact outcomes such as arrest rates or perpetrator recidivism. Instead of simply categorizing arrest laws as mandatory, preferred, and discretionary, as has been the common practice, researchers may take the more nuanced approach of testing the effects of specific elements of the laws to more precisely determine the effects of DV arrest statutes on outcomes. Depending on study design, employing such an approach may require the researcher to pinpoint implementation dates for the common elements of each law, a large undertaking to be sure. However, it may be that certain elements of the laws make them more or less effective in increasing victim safety by reducing perpetrator recidivism.

Research evaluating the implementation of these laws would allow policy analysts and advocates to better understand the steps needed to improve their effectiveness. Researchers might also look at whether officers are more likely to make "discretionary" arrests for DV in jurisdictions whose laws include both "may" and "shall arrest" provisions. The types of local policies and procedures that jurisdictions implement regarding warrantless arrest in response to state law may also differ in important ways. Research examining local responses to state legislation and resulting DV outcomes is critical to form a 
nuanced understanding of the impact of arrest laws and subsequently craft policy to reduce violence and injury.

One limitation of this research is that it only included DV arrest statutes that were found in previous DV arrest law compilations. We are satisfied that we located the relevant laws for each state; all but two of the laws included here (K.S.A. §22.2401 and 11 Del C. §1904) specifically refer to DV. However, it is possible that this research did not locate all laws that give police the authority to arrest for DV. Also, this research provides no consideration or analysis of the opinions and notes attached to each statute, nor does it look to relevant case law that might offer interpretation of state statutes. Such an investigation is beyond the scope of this research and not something commonly undertaken in policy analysis.

It is important to note that DV arrest laws regularly undergo legislative changes. This can be encouraging to advocates and policymakers, as they seek to strengthen their states' laws, and challenging for researchers, who must routinely track legislative changes. This research provides a snapshot of state warrantless arrest laws for DV perpetration as they stood in April 2010. It provides researchers information needed to undertake policy or implementation analyses of these laws. By breaking the laws down into common elements, we illuminate their differences; it is these differences that often make categorization and comparisons difficult. Although we do not offer a simple classification system, we do suggest that researchers take the common elements identified here into account when conducting their analyses. By providing this information, we hope to spur additional research on these laws and push the field forward at a faster pace than otherwise might have been seen.

\section{Declaration of Conflicting Interests}

The authors declared no potential conflicts of interest with respect to the authorship and/or publication of this article.

\section{Funding}

The authors disclosed that they received the following support for their research and/ or authorship of this article:

\section{References}

American Bar Association Commission on Domestic Violence. (2007). Domestic violence arrest policies by state. Chicago, IL: Author. 
Bazemore, G., \& Umbreit, M. (1995). Rethinking the sanctioning function in juvenile court - Retributive or restorative responses to youth crime. Crime \& Delinquency, 41, 296-316.

Beck v. Ohio, 379 U.S. 89 (1964).

Brinegar v. United States, 338 U.S. 160 (1949).

Buzawa, E. S., \& Buzawa, C. G. (1993). The impact of arrest of domestic violence. American Behavioral Scientist, 36, 558-574.

Buzawa, E. S., \& Buzawa, C. G. (2003). Domestic violence: The criminal justice response (3rd ed.). Thousand Oaks, CA: SAGE.

Catalano, S. M. (2007, December 19). Intimate partner violence in the United States. Retrieved from http://bjs.ojp.usdoj.gov/index.cfm?ty=pbdetail\&iid=1000

Cook, M. (2009, March 13). Domestic abuse arrest time expansion. Session Daily. Retrieved from http://www.house.leg.state.mn.us/hinfo/sessiondaily.asp? storyid $=1687$

Cunningham, C. (1997). Domestic violence: I don't need to have bruises to feel painA worthy exception to the warrant requirement. Pacific Law Journal, 28, 731-735.

Feder, L. (1996). Police handling of domestic calls: The importance of offender's presence in the arrest decision. Journal of Criminal Justice, 24, 481-490.

Hart, W. L. (1984). Family violence: Attorney General's Task Force final report. Washington, DC: Deptartment of Justice.

Harvey, T. L. (1994). Batterers beware: West Virginia responds to domestic violence with the probable cause warrantless arrest statute. West Virginia Law Review, 97, 181-187.

Hirschel, D., Buzawa, E., Pattavina, A., Faggiani, D., \& Reuland, M. (2007). Explaining the prevalence, context, and consequences of dual arrest in intimate partner cases. Washington, DC: National Institute of Justice.

Iyengar, R. (2006). Does the certainty of arrest reduce domestic violence? Evidence from mandatory and recommended arrest laws. Cambridge, MA: National Bureau of Economic Research.

Iyengar, R. (2009). Does the certainty of arrest reduce domestic violence? Evidence from mandatory and recommended arrest laws. Journal of Public Economics, 93, $85-98$.

Maxwell, C. D., Garner, J. H., \& Fagan, J. (2001). The effects of arrest on intimate partner violence: New evidence from the Spouse Assualt Replication Program (Research in Brief No. NCJ 188199). Washington, DC: National Institute of Justice.

Miller, M. L., \& Wright, R. F. (2007). Criminal procedures: Cases, statutes, and executive materials (3rd ed.). New York, NY: Aspen.

Miller, N. (2004). Domestic violence: A review of state legislation defining police and prosecution duties and powers. Alexandria, VA: Institute for Law and Justice. 
Miller, N. (2005). What does research and evaluation say about domestic violence laws? A compendium of justice system laws and related research assessmentsDRAFT. Alexandria, VA: Institute for Law and Justice.

Schmidt, J. D., \& Sherman, L. W. (1993). Does arrest deter domestic violence? American Behavioral Scientist, 36, 601-609.

Sherman, L. W., \& Berk, R. A. (1984). The specific deterrent effects of arrest for domestic assault. American Sociological Review, 49, 261-272.

Violence Against Women Act of 1994, 42 U.S.C. § 3796hh (1994).

Welsh v. Wisconsin, 466 U.S. 740 (1984).

\section{Bios}

April M. Zeoli is an assistant professor in the School of Criminal Justice at Michigan State University, East Lansing. She obtained an MPH from the University of Michigan and a PhD in health and public policy from the Johns Hopkins Bloomberg School of Public Health. Her main field of investigation is the prevention of intimate partner violence and homicide through public policy.

Alexis Norris is a doctoral student in criminal justice at Michigan State University. Her research interests include juvenile justice, risk and decision making, and issues related to gender and race in the criminal justice system.

Hannah Brenner is a lecturer in law at the Michigan State University College of Law. She earned her JD from the University of Iowa College of Law. She is interested in exploring innovative models for judicial and legal interventions related to intimate partner violence, as well as considering international dimensions of violence against women. 